Article

\title{
Hydrochemical and Stable Isotope Characteristics of Lake Water and Groundwater in the Beiluhe Basin, Qinghai-Tibet Plateau
}

\author{
Jinlong $\mathrm{Li}^{1,2}$, Wei Wang ${ }^{1,2, *}$, Dahao Wang ${ }^{1,2}$, Jiaqi $\mathrm{Li}^{1,2}$ and Jie Dong ${ }^{3}$ \\ 1 School of Water and Environment, Chang'an University, Xi'an 710054, Shaanxi, China; \\ 2018229017@chd.edu.cn (J.L.); 2018229001@chd.edu.cn (D.W.); 2018129018@chd.edu.cn (J.L.) \\ 2 Key Laboratory of Subsurface Hydrology and Ecological Effect in Arid Region, Ministry of Education, \\ Chang'an University, Xi'an 710054, Shaanxi, China \\ 3 Shaanxi Institute of Engineering Prospecting Co. Ltd. (SIEP), Xi'an 710068, Shaanxi, China; \\ 2016129056@chd.edu.cn \\ * Correspondence: wangweichd@chd.edu.cn; Tel.: +86-029-8233-9218
}

Received: 14 July 2020; Accepted: 10 August 2020; Published: 12 August 2020

\begin{abstract}
Thermokarst lakes are a ubiquitous landscape feature that impact the thermal state, hydrological process, ecological environment, and engineering stability of the permafrost. This study established the hydrochemistry and stable isotope $\left(\delta^{18} \mathrm{O}\right.$ and $\left.\delta \mathrm{D}\right)$ variations of lake water and groundwater in a typical basin located in the central Qinghai-Tibet Plateau (QTP) of China. The results showed that most water samples could be classified as slightly alkaline, with high levels of salinity and hardness, while the dominant water types were $\mathrm{HCO}_{3}-\mathrm{CO}_{3}$ and $\mathrm{Cl}$ types. Natural hydrochemical processes, such as mineral dissolution, cation exchange, and groundwater evaporation, had strong impacts on the groundwater chemistry in this region. Dissolution of halite and carbonate minerals causes the major reactions controlling water chemistry in this basin. Additionally, the calculation of the saturation index (SI) values suggested that aragonite, calcite, and dolomite are saturated, while halite is not. Based on the analysis of the stable isotope characteristics, atmospheric precipitation, groundwater, and meltwater from the permafrost are the major sources of thermokarst lakes. Moreover, the evaporation-to-inflow ratio (E/I) indicated that all of the lakes continuously expanded and rapidly developed. Overall, groundwater is an crucial source of lake recharge and its hydrochemical characteristics also have a certain impact on lake water quality.
\end{abstract}

Keywords: groundwater; thermokarst lake; hydrochemical characteristics; stable isotopic; Qinghai-Tibet Plateau

\section{Introduction}

The Qinghai-Tibet Plateau (QTP), known as the "third pole" of the earth, is experiencing a faster and more sensitive increase in temperatures on account of climate change than other regions at similar latitudes [1]. Permafrost degradation in the QTP resulting from global warming in recent decades has considerably affected the hydrological and ecological processes [2]. Numerous studies have emphasized that it has led to variations in hydrological conditions and redistribution of the subsurface water in the QTP [3-5]. As a result of global warming and the spread of human engineering, the thickness of the active layers is increasing, while the underlying permafrost is disappearing. In the freezing and thawing process, underground ice undergoes continuous melting and freezing in the permafrost active layer, which reduces the stability of important projects in the QTP. Many geological landscape and disasters, such as thermokarst lakes (Figure 1a), thermokarst collapse (Figure 1b), and thermokarst flow, occur as a result of such transformations. 

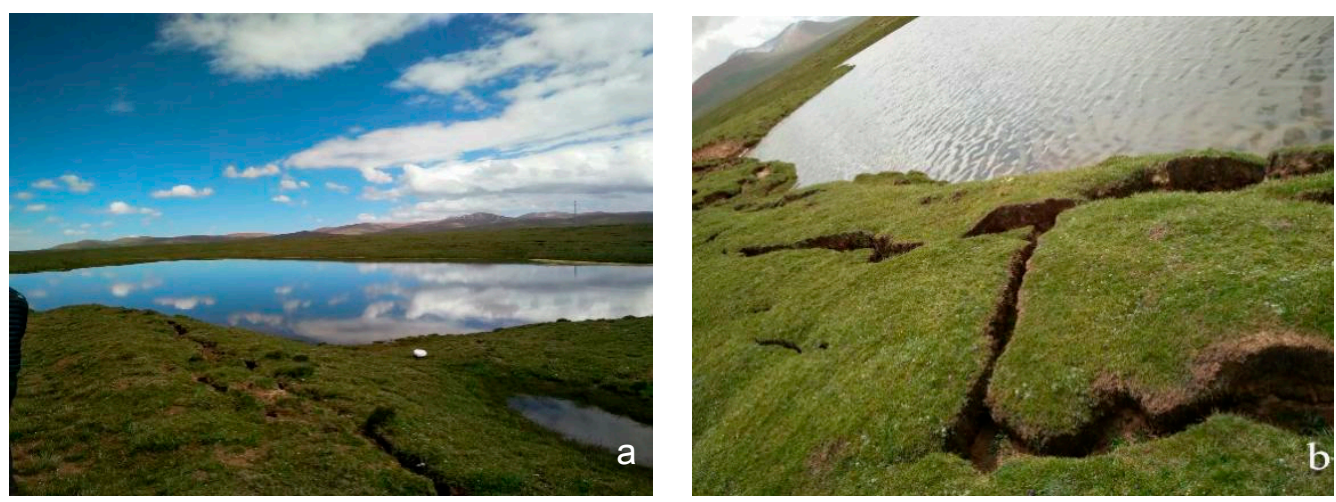

Figure 1. A representative thermokarst lake and thermokarst collapse in the Beiluhe Basin (BLB) (photographs by Jie Dong); (a) thermokarst lake; (b) thermokarst collapse.

Thermokarst lakes, which are ubiquitous in this landscape, are widely distributed in the ice-rich permafrost layer, for example in high mountains at a low latitude or pan-Arctic lowlands, such as in Siberia, Alaska, and Canada [4,5]. Thermokarst lakes were formed by the melting of massive amounts of ground ice or the thawing of ice-rich permafrost, followed by local ground subsidence and water collection in the created depressions [6]. Thermokarst lakes and their variations have a significant influence on the thermal state, hydrological processes, ecological environment, and engineering stability of the permafrost. Recent studies have identified thermokarst lakes as one of the extremely important greenhouse gas sources in nature [7-9]. A holonomic and significant mutual feed exists between thermokarst lakes and the global climate system, which is considered to be an indicator of climate and environmental changes. Therefore, studies on thermokarst lakes have contributed considerably to permafrost research in recent years [7-9]. These research studies covered the isotopic hydrology of thermokarst lakes and pointed out that the seasonal variation of stable isotope concentrations in the permanent lagoon is significantly smaller than that in the seasonal lagoon However, knowledge of fundamental hydrochemical characteristics in the permafrost area is limited, affecting the cognition and prediction of the regional hydrological cycle [9].

Studies on hydrochemistry and stable isotopes play a critical role in indicating both water origin and interactions of groundwater and surface water, thus making them significant in regional water resource management and economic development. The characteristics of water chemistry record information related to groundwater recharge source, migration, and circulation to some extent [10]. Therefore, understanding the hydrochemical characteristics of groundwater is key in determining groundwater quality and its recharge process [11]. Traditional hydrochemical methods such as Piper maps and Gibbs maps have been widely used to determine the hydrochemical characteristics and evolution of groundwater [12-16]. Stable isotope geochemistry plays a critical role in monitoring climate change with an accurate recording of paleoenvironment variations $[17,18]$. The $\delta \mathrm{D}$ and $\delta^{18} \mathrm{O}$ (which are both stable isotope tracers, effectively applying for identifying hydrological conditions) values are significantly affected by variations in the water source, topography, precipitation, and hydrological and climatic processes in both lakes and surround groundwater [19]. Thus, stable isotopes of $\delta \mathrm{D}$ and $\delta^{18} \mathrm{O}$ have a wide range of applications in evaluating the source and recharge of groundwater and indicating the interaction between groundwater and surface water in different regions. The $\delta \mathrm{D}$ and $\delta^{18} \mathrm{O}$ values and ion concentrations are useful tools for studying the hydrological processes of lakes on the Tibetan Plateau [20-22]. Wang et al. (2018) established stable isotope variations in three lakes of the QTP, suggesting that $\delta^{18} \mathrm{O}$ values were dominated by the evaporation/freshwater input ratios [20]. Gao et al. (2018) investigated a large number of thermokarst lakes and ponds in the QTP and found that the mean isotope compositions in these thermokarst lakes were $-7.2 \%$ in $\delta^{18} \mathrm{O}$ and $-58.0 \%$ in $\delta \mathrm{D}$ [21]. Yang et al. (2016) demonstrated that thermokarst lake water was contributed at a rate of $61.3 \%$ by the melting of ice-rich permafrost [21]. However, monitoring the lake hydrology in the QTP has proven to be difficult owing to logistical challenges and some uncertainties in the field 
while surveying [6]. Despite extensive studies having focused on hydrochemical processes and the stable isotope geochemistry of groundwater and lake water, the fundamental mechanisms responsible for the development and progression of thermokarst lakes from the above two perspective have not yet been fully elucidated.

In this study, a typical complete watershed with a considerable distribution of thermokarst lakes in the Beiluhe Basin (BLB), where many sites have been set up, was considered as the research object. Specifically, we attempted to compare the degree of increase in $\delta \mathrm{D}$ and $\delta^{18} \mathrm{O}$ values to identify the relationship between the groundwater and lake water. Additionally, the development state of the lake could be determined by calculating the evaporation-to-inflow ratios (E/I) of different lakes. The goal was to clarify the main hydrological and geochemical effects of thermokarst lakes during the melting of the frozen soil in summer, which was analyzed on the basis of the different ion proportions of the dissolved mineral components of the groundwater and lake water.

\section{Materials and Methods}

\subsection{Study Area}

\subsubsection{Physiography and Meteorology}

The hydrological regimes of thermokarst lakes in the QTP are expected to be varied and complex as a direct result of global warming, so studies need to be conducted at lake-specific levels to improve the comprehensive science-based monitoring programs for adequate assessment of the water balance and hydrological processes in the QTP [6]. Therefore, this study was conducted in the BLB, which is a typical complete watershed with a large distribution of thermokarst lakes and is located in Yushu Tibetan Autonomous Prefecture, Qinghai Province, China (Figure 2).
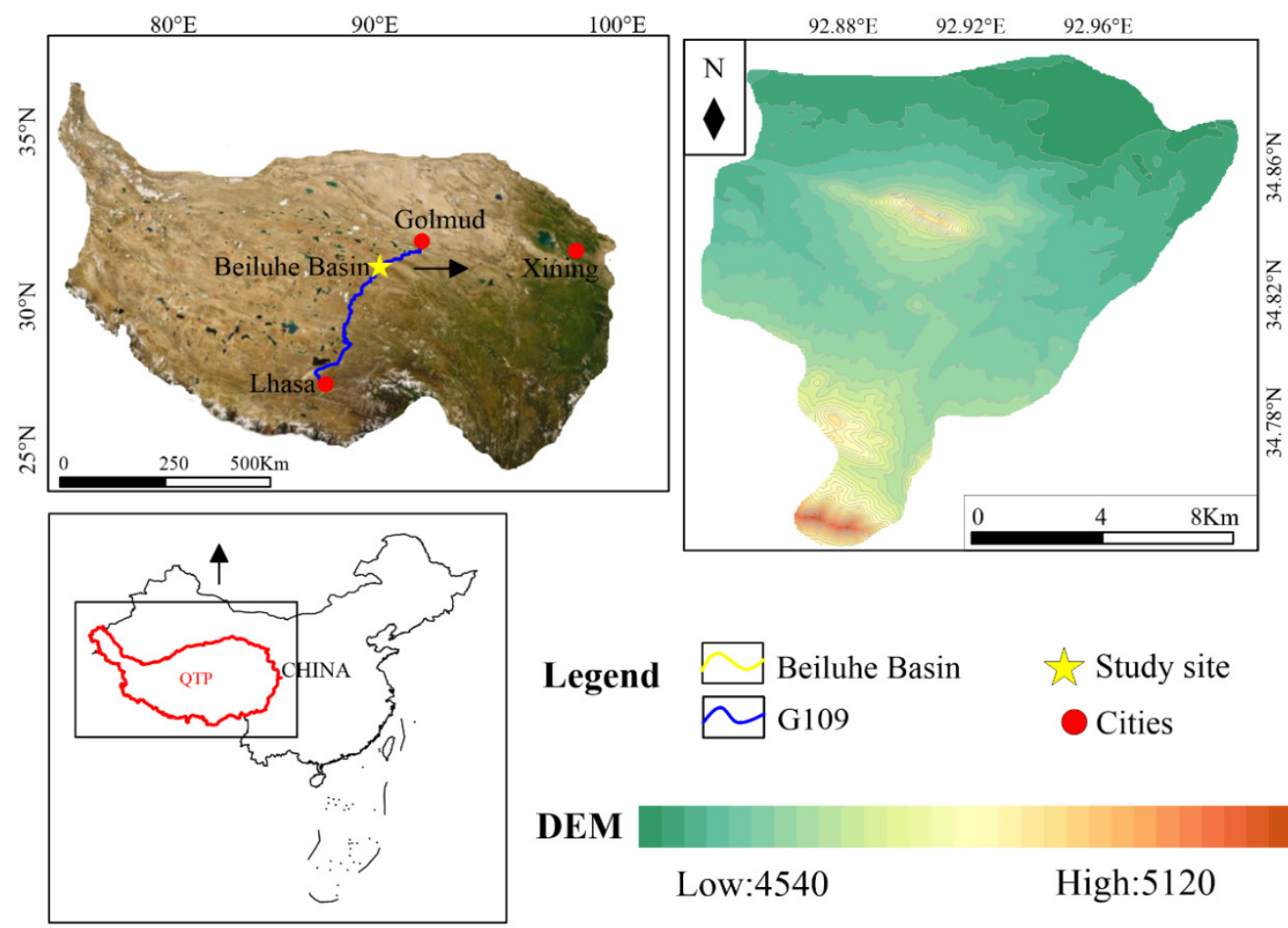

Figure 2. Location of the study area.

The BLB extends $4.17 \mathrm{~km}$ south to north and $2.72 \mathrm{~km}$ west to east, covering $11.52 \mathrm{~km}^{2}$. The BLB has a semi-arid climate and is in the sub-cold zone of the QTP, with strong solar radiation and sufficient 
sunlight; the annual sunshine hours are between 2200 and $2900 \mathrm{~h}$. The mean annual average ground temperature varies from -1.8 to $-0.5^{\circ} \mathrm{C}$ and has risen at a rate of $0.03{ }^{\circ} \mathrm{C} / \mathrm{a}$. According to the measured data from the Wudaoliang and Tuotuohe meteorological stations, the mean annual evaporation in the study area is $274.7 \mathrm{~mm}$, and the high evaporation rates-the annual average evaporation is $1421.4 \mathrm{~mm}$-are attributed to the westerly cold and dry air masses [23]. The study region is located in the permafrost area, with an active layer thickness of 1.5-2.5 $\mathrm{m}$ and permafrost layer thickness of 30-100 m. Precipitation mainly consists of rainfall, snow, and hail, most of which occurs from June to September.

\subsubsection{Local Geology and Hydrogeology}

From top to bottom, the lithology of the sedimentary strata in the study area is as follows (Figure 3) - the Quaternary Holocene alluvial layer and the Neogene lacustrine sedimentary layer. The upper part of the Quaternary Holocene alluvial layer is composed of silt with a fine sand layer; it is brownish-red in color, with a thickness of about 0.5-3.5 m. Furthermore, the lower part is composed of a clay layer with a brownish-red color and a thickness of $1 \mathrm{~m}$. In addition, the Neogene lacustrine sedimentary layer consists of mudstone and sandstone. Mudstone, the dominant lithology, is brownish-red with strong weathering and good fracture development. Sandstone, which is occasionally in the middle of the mudstone, is brownish-red, intensely weathered, and mostly calcareous argillaceous cementation. The depth of the upper permafrost limit is generally between 1.5 and $2.5 \mathrm{~m}$, with a thickness of about $10-50 \mathrm{~m}$.

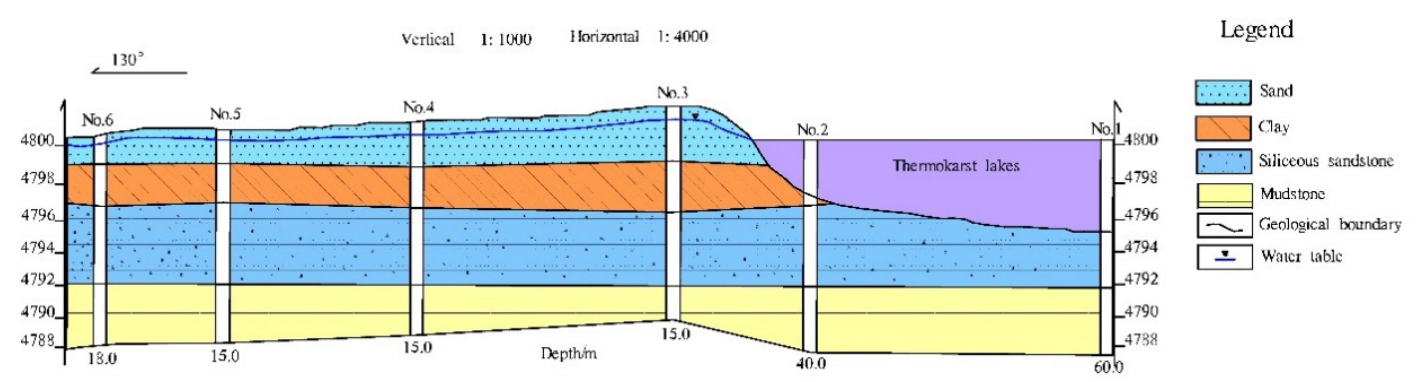

Figure 3. Hydrogeological cross section.

According to the relationship between the aquifer and the multi-year permafrost layer [24], the permafrost water is divided into the (A) upper permafrost water, (B) middle permafrost water, and (C) bottom permafrost water (Figure 4). The upper permafrost water is the most widely distributed groundwater in the study region, which has dynamic characteristics with very obvious seasonal changes. The thickness of the aquifer is generally $1-2 \mathrm{~m}$ and the specific discharge is generally $0.2-10 \mathrm{~L} / \mathrm{s}$. The water sampling depth is between 2 and $3 \mathrm{~m}$ because of the limitations of the arduous sampling conditions, which are closely related to the lake. Therefore, the groundwater mentioned hereinafter refers to the upper water. 


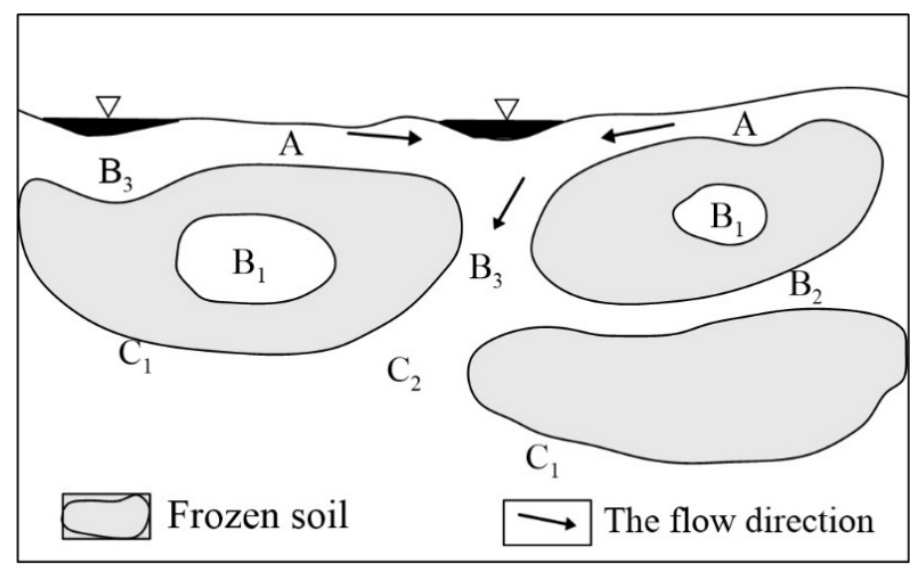

Figure 4. Schematic of groundwater types in permafrost areas [25]: (A) upper permafrost water; (B1) water in middle permafrost; (B2) water between permafrost layers; (B3) channel water of freeze-thaw zone; (C1) direct contact water in bottom permafrost; (C2) non-direct-contact water in bottom permafrost.

Permafrost aquifers are mainly recharged by atmospheric precipitation and melted snow, which are primarily controlled by the topography of the area. The groundwater in the area mainly evaporates and discharges in the form of springs into the thermokarst lake. Additionally, a small amount of water is discharged into the bottom permafrost through the direct contact channel.

\subsection{Sampling and Analysis}

The thermokarst lake is distributed in the QTP, which has an average altitude of over $4000 \mathrm{~m}$ above mean sea level (m.s.l.) with a cold climate [26-28], making it difficult for sampling. In order to investigate the hydrological dynamics of the lakes and groundwater, a total of 51 water samples (including 16 lake water samples, 11 groundwater samples, 1 rain sample, and 23 isotopic water samples) were acquired from 11 boreholes and 8 lakes spanning the permafrost regions of the BLB (Figure 5). Limited by the field conditions, the sampling depth was generally $2-3 \mathrm{~m}$. All groundwater samples were upper permafrost water and closely related to lake water. Each water sample was collected in two $550 \mathrm{~mL}$ polyethylene (PE) bottles and each isotopic sample was collected in two $80 \mathrm{~mL}$ high-density polyethylene (HDPE) bottles. All samples were taken and stored according to the corresponding method as per, "Water Quality Sampling-Technical Regulation of the Preservation and Handling of Samples (2019)", published by the Ministry of Environmental Protection of the P.R.C. 


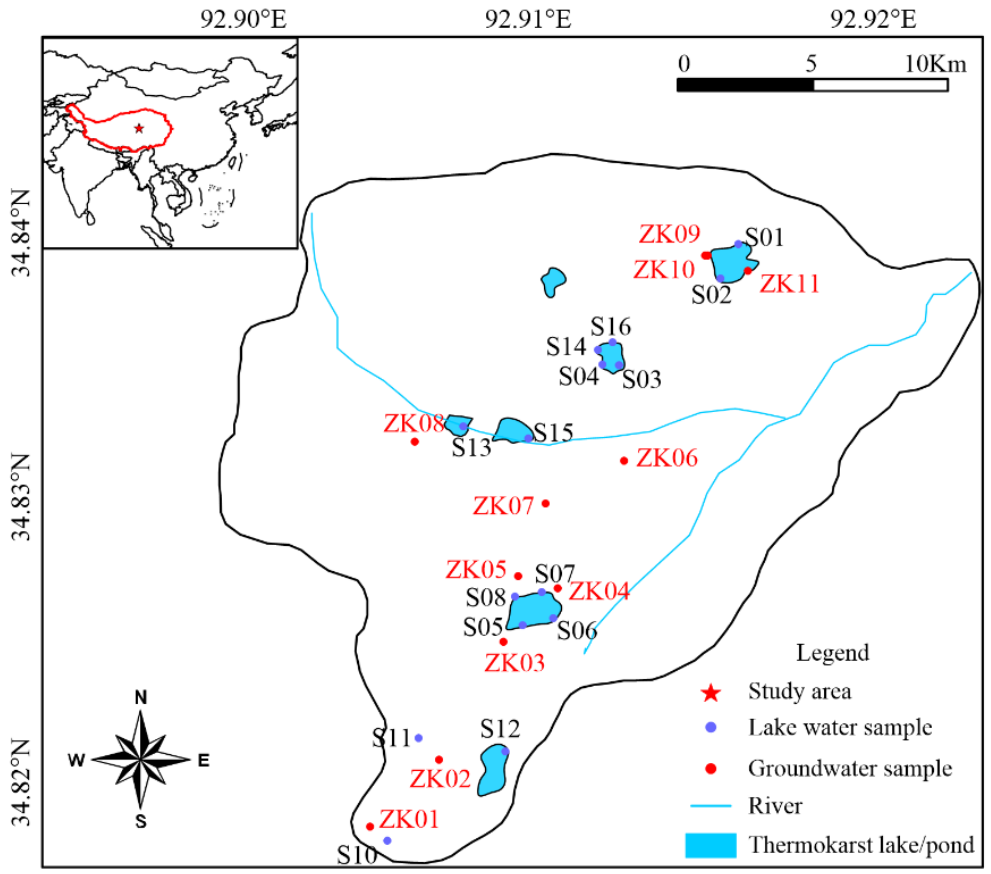

Figure 5. Locations of the sampling sites.

The $\mathrm{pH}$ values of all of the samples were analyzed on site using a $\mathrm{pH}$ acidimeter (PHS_3E), while the concentrations of cations $\left(\mathrm{K}^{+}, \mathrm{Na}^{+}, \mathrm{Ca}^{2+}, \mathrm{NH}_{4}{ }^{+}\right.$, and $\left.\mathrm{Mg}^{2+}\right)$, anions $\left(\mathrm{CO}_{3}{ }^{2-}, \mathrm{HCO}_{3}{ }^{-}, \mathrm{F}^{-}, \mathrm{SO}_{4}{ }^{2-}\right.$, $\mathrm{NO}_{2}{ }^{-}, \mathrm{NO}_{3}{ }^{-}$, and $\left.\mathrm{Cl}^{-}\right)$, total hardness (TH), and total dissolved solids (TDS) were computed at the Water and Soil Testing Center of Shaanxi Institute of Engineering Prospecting Co. Ltd. (SIEP), China. The concentrations of $\mathrm{Cl}^{-}, \mathrm{SO}_{4}{ }^{2-}, \mathrm{HCO}_{3}{ }^{-}$, and $\mathrm{NH}_{4}{ }^{+}$were verified via titrimetric methods, while $\mathrm{Na}^{+}$ and $\mathrm{K}^{+}$concentrations were determined by atomic absorption spectroscopy, with an accuracy error rate of less than $1 \%$ (atomic absorption spectrophotometer, TAS990). $\mathrm{Ca}^{2+}, \mathrm{Mg}^{2+}$, and TH concentrations were ascertained by the EDTA titrimetric method. The traditional drying and weighing approach was used to determine TDS concentrations. In addition, $\mathrm{F}^{-}, \mathrm{NO}_{3}-\mathrm{N}$, and $\mathrm{NO}_{2}-\mathrm{N}$ concentrations were calculated by the ion-selective electrode method and ion chromatography (Precision ion Meter). Additionally, the permanganate index $\left(\mathrm{COD}_{\mathrm{Mn}}\right)$ was analyzed via the titrimetric method with potassium permanganate $\left(\mathrm{KMnO}_{4}^{-}\right)$as the oxidant.

The particle sizes of all of the borehole soil samples were confirmed by using the Bettersize 2000 laser particle size analyzer, for which the range of determination is $0.02-2000 \mu \mathrm{m}$, the accuracy error is less than $1 \%$, and the Mie scattering theory was applied. The mineral composition was determined at the laboratory center of the Xi'an Geological Survey Center (Ministry of Natural Resources of China), using a D/MAX 2500 X-ray diffractometer. Further, all of the isotopic water samples were transported for analysis of water-stable isotopes $\left(\delta \mathrm{D}\right.$ and $\left.\delta^{18} \mathrm{O}\right)$ and were analyzed with a Picarro L2140-i isotopic analyzer, for which the measurement accuracy values for $\delta \mathrm{D}$ and $\delta^{18} \mathrm{O}$ can reach 0.5 and $0.1 \%$, respectively.

A detailed classification laboratory analysis is the primary step, using the Piper diagrams and Durov diagrams. Using data from the Gibbs diagram, ion ratios, and the saturation index collectively, one may assess the impact of the hydrochemical process on the groundwater and lake water. Furthermore, analysis of isotopes could be especially useful in order to verify the evaporation intensity of lakes. 


\section{Results and Discussion}

\subsection{Major Ion Chemistry}

Statistical analysis of the major ions is the basis of understanding the hydrochemical characteristics of water [29]. Statistical analysis results for the physicochemical parameters of the major ions are shown in Table 1.

Table 1. Statistical analysis results for major ion concentrations $(\mathrm{mg} / \mathrm{L})$ in groundwater and lake water.

\begin{tabular}{cccccccc}
\hline Parameter & \multicolumn{3}{c}{ Groundwater } & \multicolumn{3}{c}{ Lake Water } & Precipitation \\
\hline & Min & Max & Mean & Min & Max & Mean & \\
\hline $\mathrm{K}^{+}$ & 3.08 & 13.7 & 6.34 & 2.02 & 6.288 & 3.37 & 3.37 \\
$\mathrm{Na}^{+}$ & 111 & 397 & 187.36 & 22.5 & 400.25 & 132.06 & 132.06 \\
$\mathrm{Ca}^{2+}$ & 58.1 & 160 & 110.97 & 27.05 & 42.1 & 34.34 & 34.34 \\
$\mathrm{Mg}^{2+}$ & 18.2 & 115 & 56.16 & 15.1 & 92.63 & 41.19 & 41.19 \\
$\mathrm{NH}_{4}^{+}$ & 0.031 & 0.26 & 0.18 & $0.03 \mathrm{~L}$ & 0.31 & 0.17 & 0.17 \\
$\mathrm{Cl}^{-}$ & 128 & 851 & 284.73 & 28.4 & 680 & 213.27 & 213.27 \\
$\mathrm{HCO}_{3}{ }^{-}$ & 293 & 781 & 507.55 & 170 & 256 & 216.38 & 216.38 \\
$\mathrm{SO}_{4}^{2-}$ & 9.61 & 134 & 56.66 & 4.8 & 31.2 & 10.7 & 10.7 \\
$\mathrm{~F}^{-}$ & 0.28 & 0.76 & 0.45 & 0.2 & 0.45 & 0.27 & 0.27 \\
$\mathrm{TDS}^{-}$ & 468 & 1780 & 956.9 & 204 & 1420 & 563 & 563 \\
$\mathrm{pH}$ & 7.24 & 8.07 & 7.55 & 8.09 & 9.43 & 9 & 9 \\
\hline
\end{tabular}

Overall, mean concentrations of the major ions in groundwater samples are higher than lake water. $\mathrm{Na}^{+}$, which ranged from 111 to $397 \mathrm{mg} / \mathrm{L}$ for groundwater and 22.5 to $400.25 \mathrm{mg} / \mathrm{L}$ for lake water, is the dominant cation in the study region. Both dissolutions of halite and cation exchange can increase the concentration of $\mathrm{Na}^{+}$. After $\mathrm{Na}^{+}, \mathrm{Ca}^{2+}$ is the second-largest cation of the study region, with mean concentrations of $110.97 \mathrm{mg} / \mathrm{L}$ for groundwater and $34.34 \mathrm{mg} / \mathrm{L}$ for lake water. The maximum $\mathrm{Ca}^{2+}$ concentration was observed from location ZK03 at $160 \mathrm{mg} / \mathrm{L}$. Classically, the dissolution of dolomite, limestone, and lime colloid in rocks is the ultimate origin of $\mathrm{Ca}^{2+}$. In the study region, the calcareous cement, which is mainly composed of calcite, can be dissolved due to interaction with the groundwater. Thus, the dissolution of calcareous cement is the main source of the $\mathrm{Ca}^{2+}$ ion content in groundwater here. The concentrations of $\mathrm{Mg}^{2+}$ ranged between 18.2 and $115 \mathrm{mg} / \mathrm{L}$ for groundwater, and between 15.1 and $92.63 \mathrm{mg} / \mathrm{L}$ for lake water. In total, the mean concentrations of cations in the groundwater samples were in the order of $\mathrm{Na}^{+}>\mathrm{Ca}^{2+}>\mathrm{Mg}^{2+}>\mathrm{K}^{+}$, which is consistent with the lake water.

$\mathrm{HCO}_{3}{ }^{-}$ranged from $293 \mathrm{mg} / \mathrm{L}$ to $781 \mathrm{mg} / \mathrm{L}$ for groundwater and from $170 \mathrm{mg} / \mathrm{L}$ to $256 \mathrm{mg} / \mathrm{L}$ for lake water, with mean values of 507.55 and $216.38 \mathrm{mg} / \mathrm{L}$, respectively. Thus, $\mathrm{HCO}_{3}{ }^{-}$, which was taken as the dominant anion in water samples, is several orders of magnitude larger than other anions, such as $\mathrm{SO}_{4}{ }^{2-}$ and $\mathrm{F}^{-}$. The variation of $\mathrm{HCO}_{3}{ }^{-}$in groundwater tends to be consistent with that of $\mathrm{Mg}^{2+}$, which almost comes from dissolution of carbonate. The concentrations of $\mathrm{Cl}^{-}$were between 128 and $851 \mathrm{mg} / \mathrm{L}$ for groundwater, and between 28.4 and $680 \mathrm{mg} / \mathrm{L}$ for lake water. $\mathrm{CO}_{3}{ }^{2-}, \mathrm{NO}_{3}{ }^{-}$, and $\mathrm{NO}_{2}{ }^{-}$were not included in the tables because their concentrations were substantially lower than the detection limit. Furthermore, the box line diagram of the ion concentrations in the groundwater and lake water is shown to understand the variations in the major ion concentrations (Figure 6). 


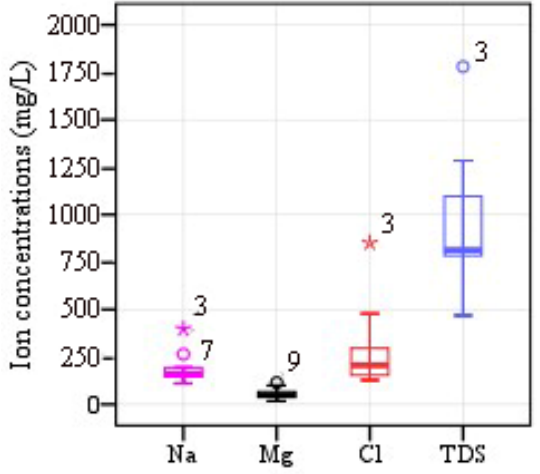

(a)

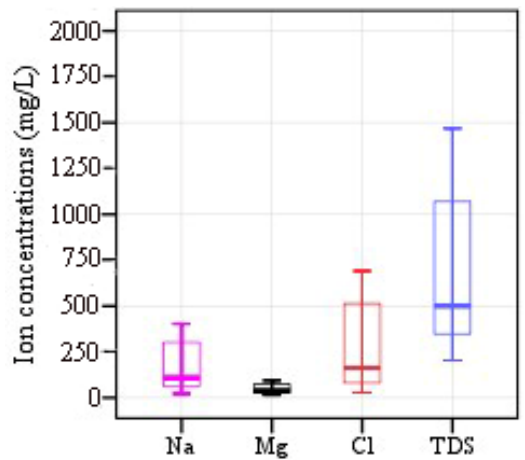

(b)

Figure 6. Box line diagram of major ions concentrations of groundwater (a) and lake water (b). (Since there is little difference in the other ion concentrations between the groundwater and lake water, only $\mathrm{Na}, \mathrm{Mg}, \mathrm{Cl}$, and TDS data are selected for plotting.)

TDS and $\mathrm{pH}$ are two important indices in assessing water quality [30]. From Table 1, the mean $\mathrm{pH}$ value of groundwater samples is 7.55 (i.e., weakly alkaline), while for lake water is 9. The TDS is lower in the northern part than in the south, and the highest is $1780 \mathrm{mg} / \mathrm{L}$ at ZK03, suggesting that the water chemistry reaction is more intense in the surrounding area.

\subsection{Water Types}

The Piper diagram and Durov diagram are both simple and widely utilized methods for determining the type of water [31]. A large number of water quality analysis data can be directly projected on the Piper diagram and the distribution of water sample points can be observed directly, which facilitates the analysis and interpretation of hydrogeochemical problems. The Piper diagram (Figure 7) indicates whether $\mathrm{HCO}_{3}-\mathrm{CO}_{3}$ type or $\mathrm{Cl}$ type are present in both the groundwater and lake water. Furthermore, there is no dominant cation type in the groundwater, while in the lake water there is either no dominant type or the Na type is dominant.

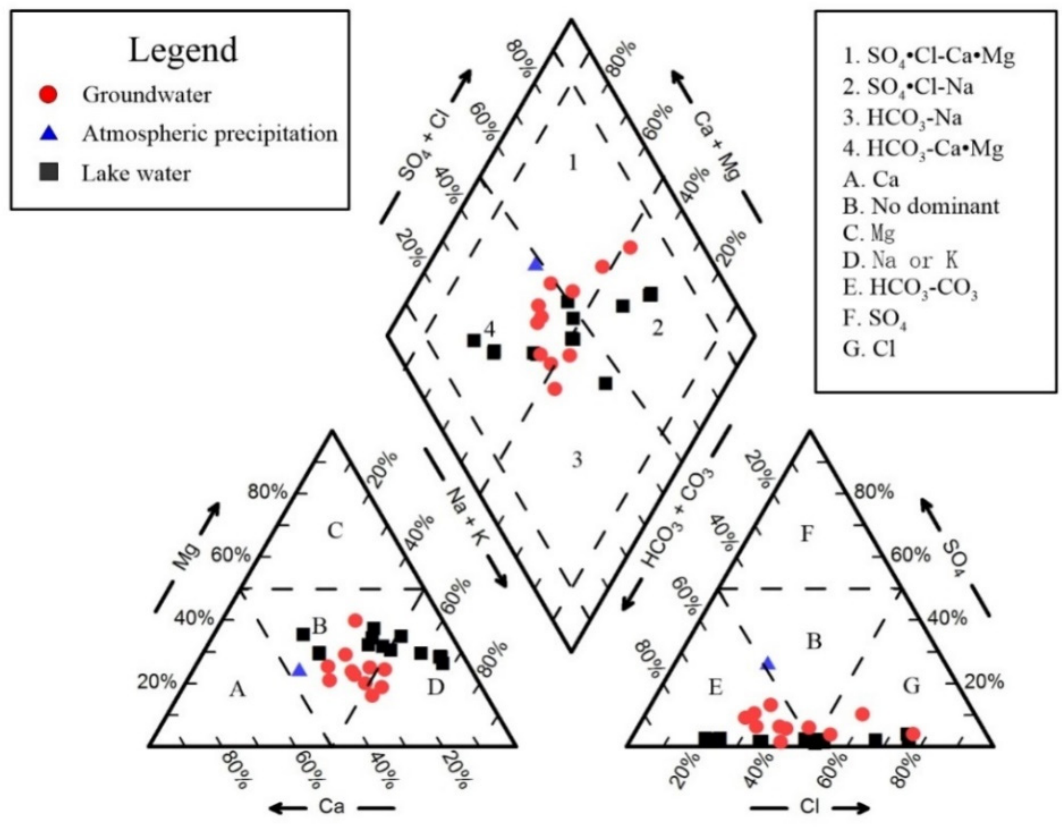

Figure 7. Piper graph. 
In order to directly analyze the basic hydrochemical characteristics of lakes, seven conventional ions, TDS, and $\mathrm{pH}$ indices were projected on the Durov diagram (Figure 8). The Durov diagram of the groundwater indicates that most of the southern groundwater samples correspond to the $\mathrm{Cl}-\mathrm{Na}$ type, while most of the northern and central groundwater samples correspond to the $\mathrm{HCO}_{3} \cdot \mathrm{CO}_{3}-\mathrm{Na}$ type. Furthermore, most of the southern lake water samples correspond to the Cl-Na type, while most of the northern and central lake water samples correspond to the $\mathrm{HCO}_{3} \cdot \mathrm{CO}_{3}-\mathrm{Na}$ type (Figure 9).

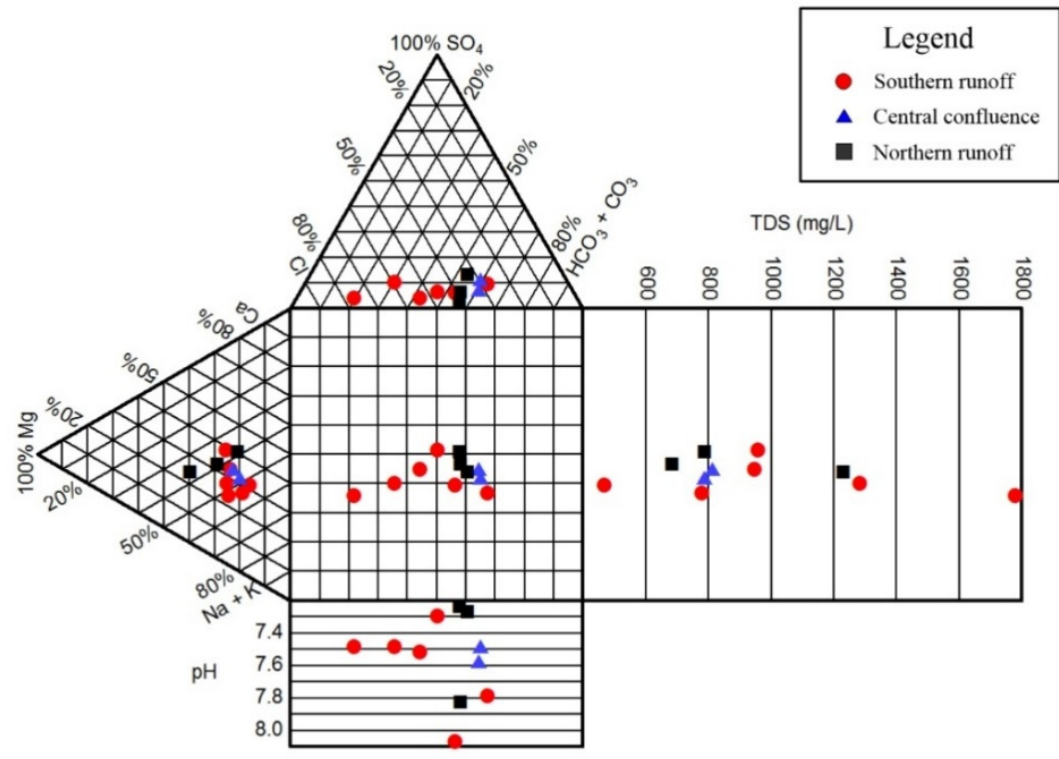

Figure 8. Groundwater Durov graph.

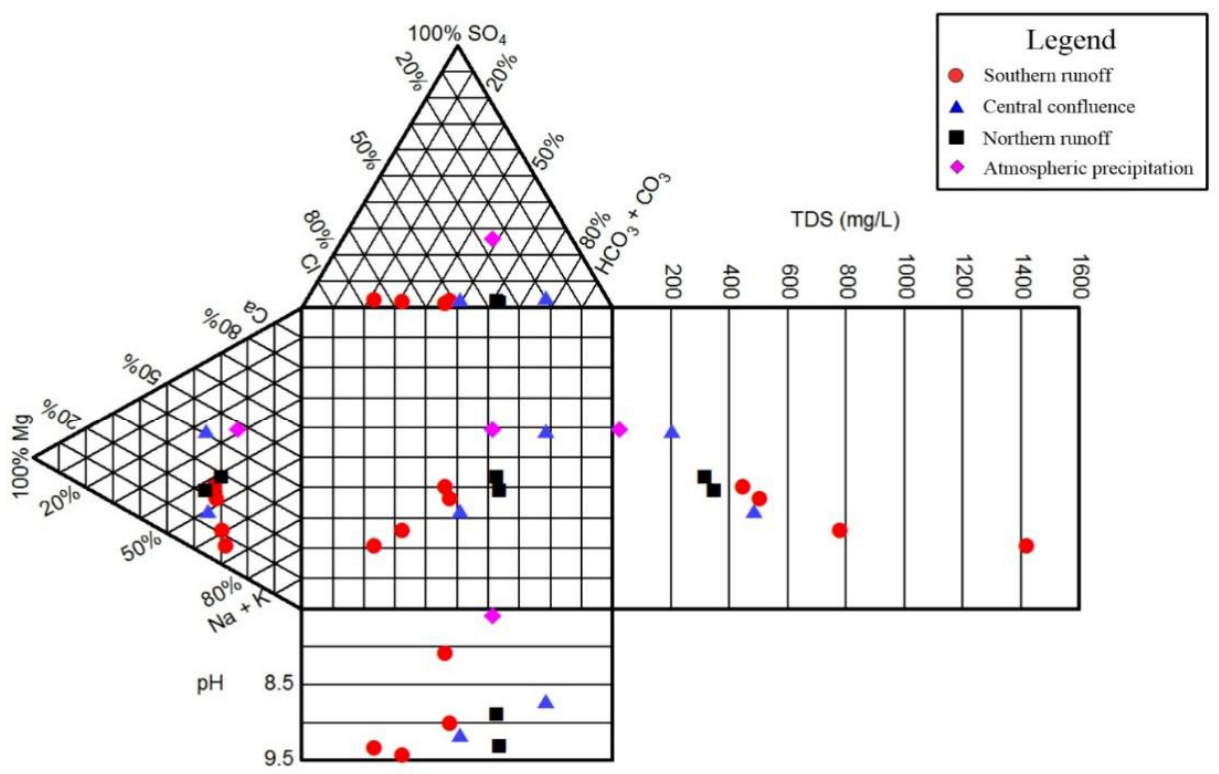

Figure 9. Lake water Durov graph.

\subsection{Processes Influence Water Chemistry}

The Gibbs diagram is regarded as an effective method used to identify the influencing factors of the water hydrochemistry through comparing the concentration of TDS versus the weight ratios of $\mathrm{Na}^{+} /\left(\mathrm{Na}^{+}+\mathrm{Ca}^{2+}\right)$ or TDS versus the weight ratios of $\mathrm{Cl}^{-} /\left(\mathrm{Cl}^{-}+\mathrm{HCO}_{3}{ }^{-}\right)$[32]. The Gibbs diagram (Figure 10) suggested that the results for all groundwater samples are concentrated in the middle and upper parts of the Gibbs diagram, corresponding to evaporative crystallization and rock weathering. 
Results for the water samples of L01, L03, and L05 lakes correspond to evaporative crystallization and rock weathering. Further, the results for L02 and L04 lakes are located near the area corresponding to the evaporative crystallization (outside the distribution curve), while those for L07 and L08 lakes are located in the area corresponding to rock weathering.

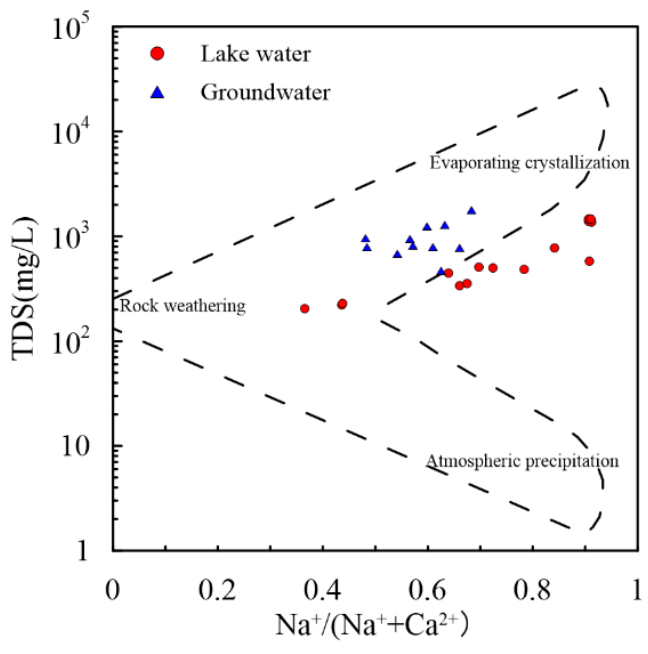

(a)

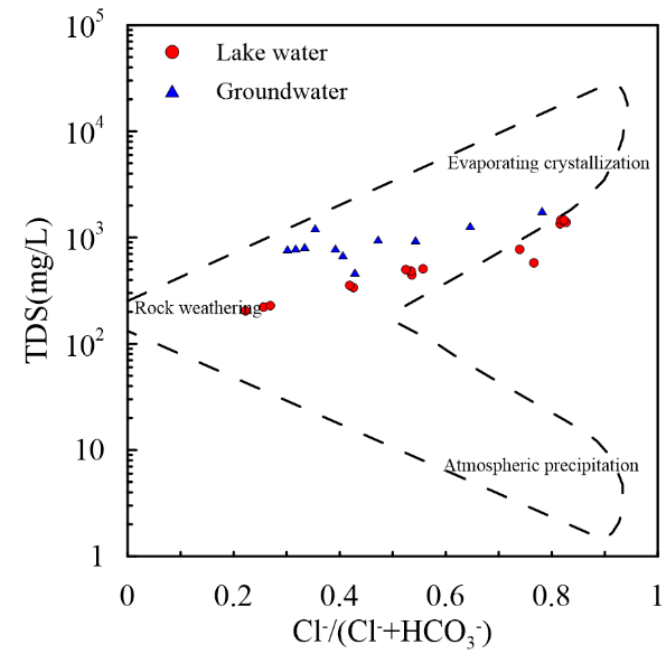

(b)

Figure 10. Gibbs diagrams of (a) $\mathrm{Na}^{+} /\left(\mathrm{Na}^{+}+\mathrm{Ca}^{2+}\right)$ and (b) $\mathrm{Cl}^{-} /\left(\mathrm{Cl}^{-}+\mathrm{HCO}_{3}{ }^{-}\right)$.

Ion exchange was also investigated by using the chloroalkaline indices (CAI-I and CAI-II) proposed by Schoeller [33]. If both CAI-I and CAI-II are negative, there is a positive reaction of cationic alternating adsorption in groundwater. Contrarily, if CAI-I and CAI-II are both positive, the inverse reaction of cationic alternating adsorption occurs in groundwater.

$$
\begin{gathered}
\text { CAI-I }=\frac{\mathrm{Cl}^{-}-\left(\mathrm{Na}^{+}+\mathrm{K}^{+}\right)}{\mathrm{Cl}^{-}} \\
\text {CAI-II }=\frac{\mathrm{Cl}^{-}-\left(\mathrm{Na}^{+}+\mathrm{K}^{+}\right)}{\mathrm{HCO}_{3}{ }^{-}+\mathrm{SO}_{4}{ }^{2-}+\mathrm{CO}_{3}{ }^{2-}+\mathrm{NO}_{3}{ }^{-}}
\end{gathered}
$$

The calculation results (Figures 11 and 12) indicate that the directions of alternating adsorption of cations in different areas of groundwater are different. The reverse reaction of the alternate adsorption of the cations occurred in the southern areas with higher concentrations of TDS and $\mathrm{Na}^{+}$, while the positive reaction of the alternate adsorption of the cations occurred in the areas where the concentrations of the TDS and $\mathrm{Na}^{+}$are lower in the southern, central, and northern regions (ZK09). However, there is little alternating adsorption of cations in other regions in the north. The general cation exchange capacity of the lake water is lower than that of the groundwater, but the reaction direction of adsorption in the case of lake water is the same as that in the case of groundwater, except in the case of L01. 
a

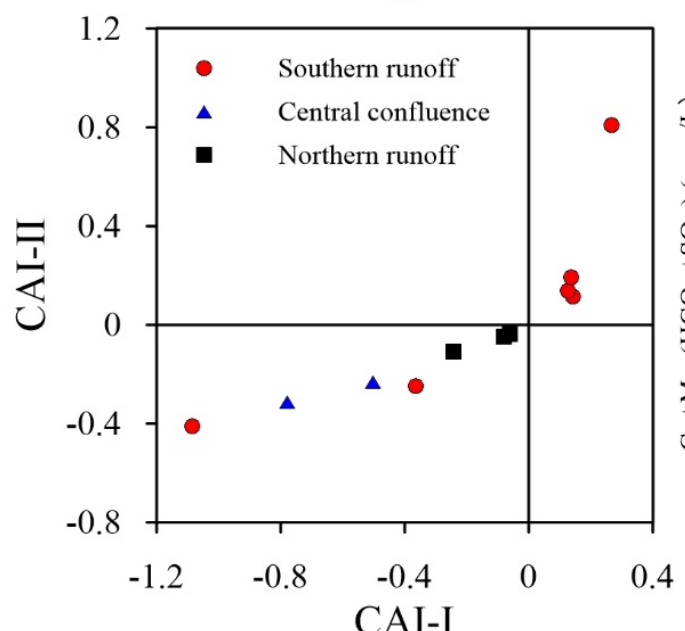

$\mathrm{b}$

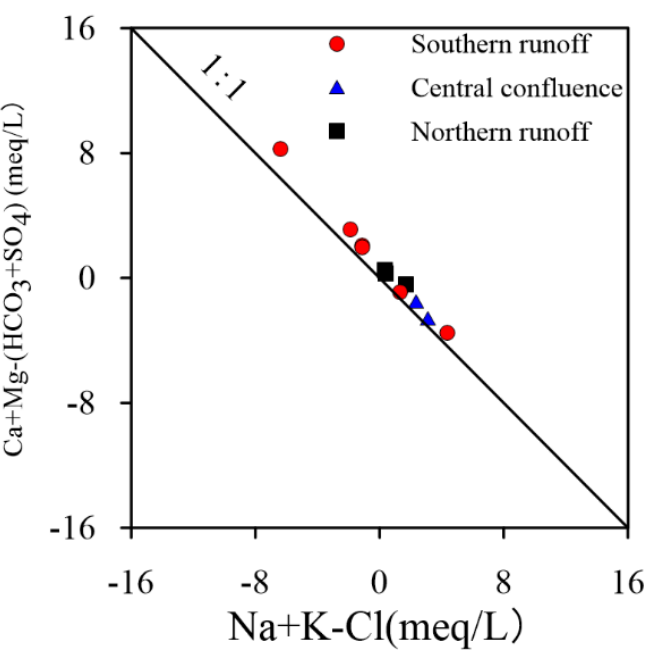

Figure 11. (a) CAI-I and CAI-II for (b) $\left[(\mathrm{Ca}+\mathrm{Mg})-\left(\mathrm{HCO}_{3}+\mathrm{SO}_{4}\right)\right]$ and $[(\mathrm{Na}+\mathrm{K})-\mathrm{Cl}]$ in groundwater.
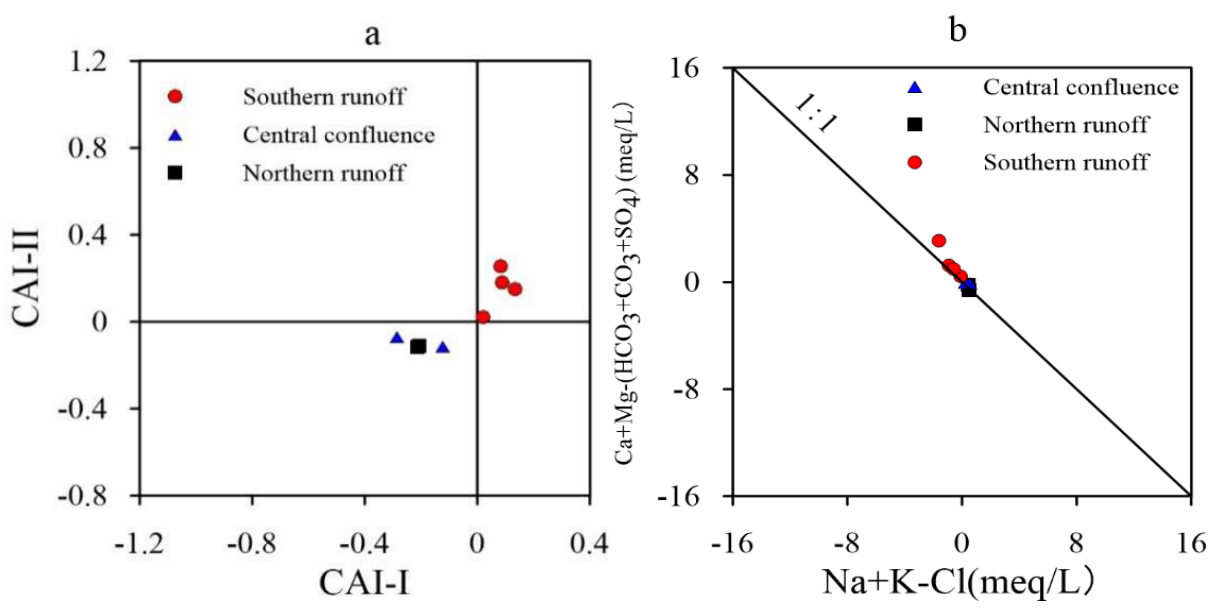

Figure 12. (a) CAI-I and CAI-II for (b) $\left[(\mathrm{Ca}+\mathrm{Mg})-\left(\mathrm{HCO}_{3}+\mathrm{SO}_{4}\right)\right]$ and $[(\mathrm{Na}+\mathrm{K})-\mathrm{Cl}]$ in lake water.

A comparison of the hydrochemical characteristics of lakes and groundwater shows that $\mathrm{CO}_{3}{ }^{2-}$ is present in lakes, but not in all groundwater samples. In contrast to the groundwater, most lakes in the southern region show the inverse reaction of cationic alternating adsorption because of the limited contact between lakes and surrounding media, but for which the exchange capacity is much lower than that of the groundwater. In addition, there is almost no alternating adsorption of cations for lakes in the central and northern regions. The $\mathrm{CO}_{3}{ }^{2-}$ content of lake water samples at $5.6^{\circ} \mathrm{C}$ is significantly lower than that at $20^{\circ} \mathrm{C}$. Additionally, the average $\mathrm{CO}_{3}{ }^{2-}$ concentration of the lake water samples is $22.4 \mathrm{mg} / \mathrm{L}$, but no $\mathrm{CO}_{3}{ }^{2-}$ is not detected in groundwater samples.

Ion ratio graphs have commonly been used to further determine the formation process and main hydrochemical components of the water samples [32]. The ion ratios of groundwater and lake water are shown in Figures 13 and 14, respectively. 

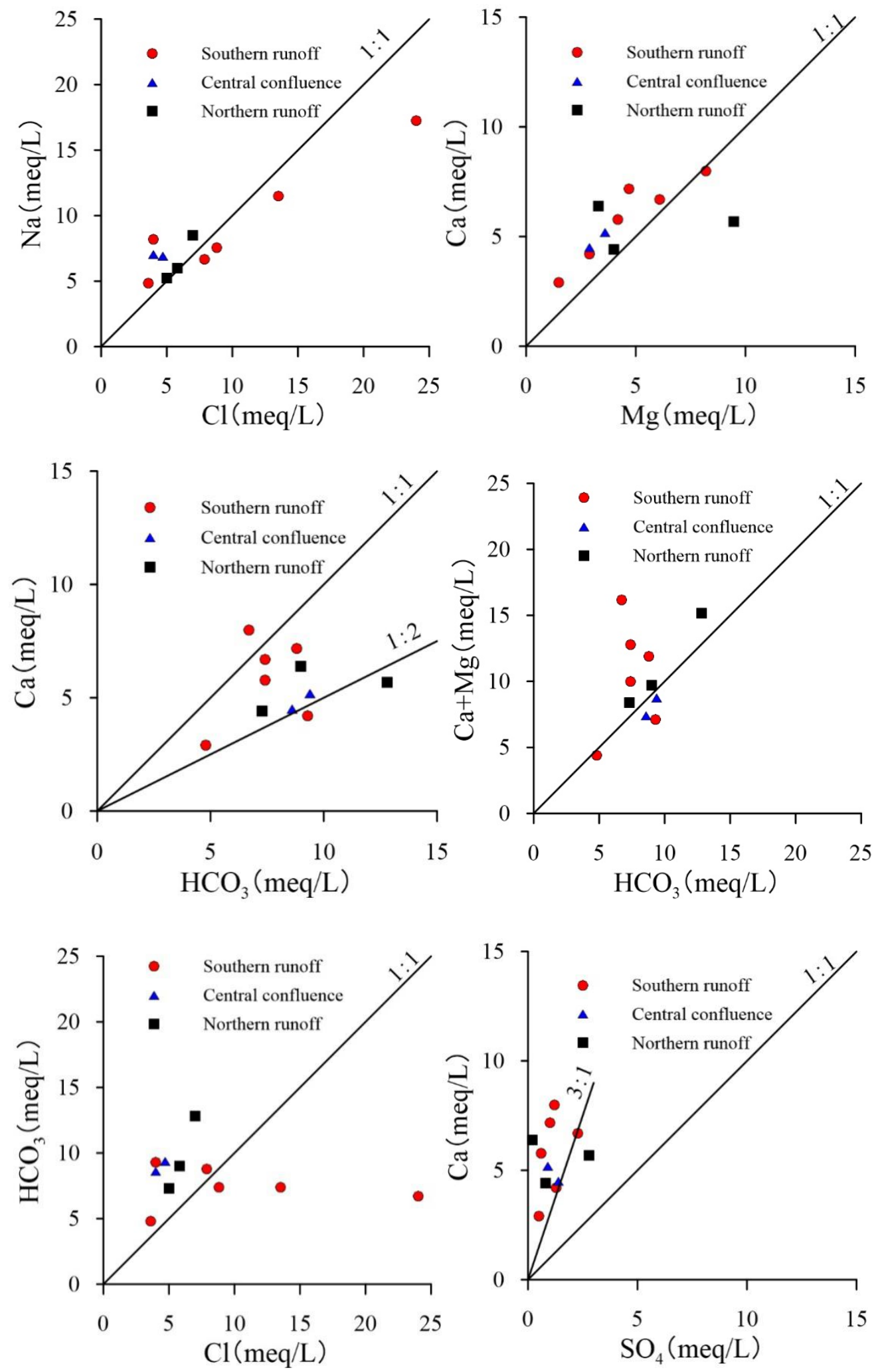

Figure 13. Bivariate diagrams of ionic concentrations in groundwater. 

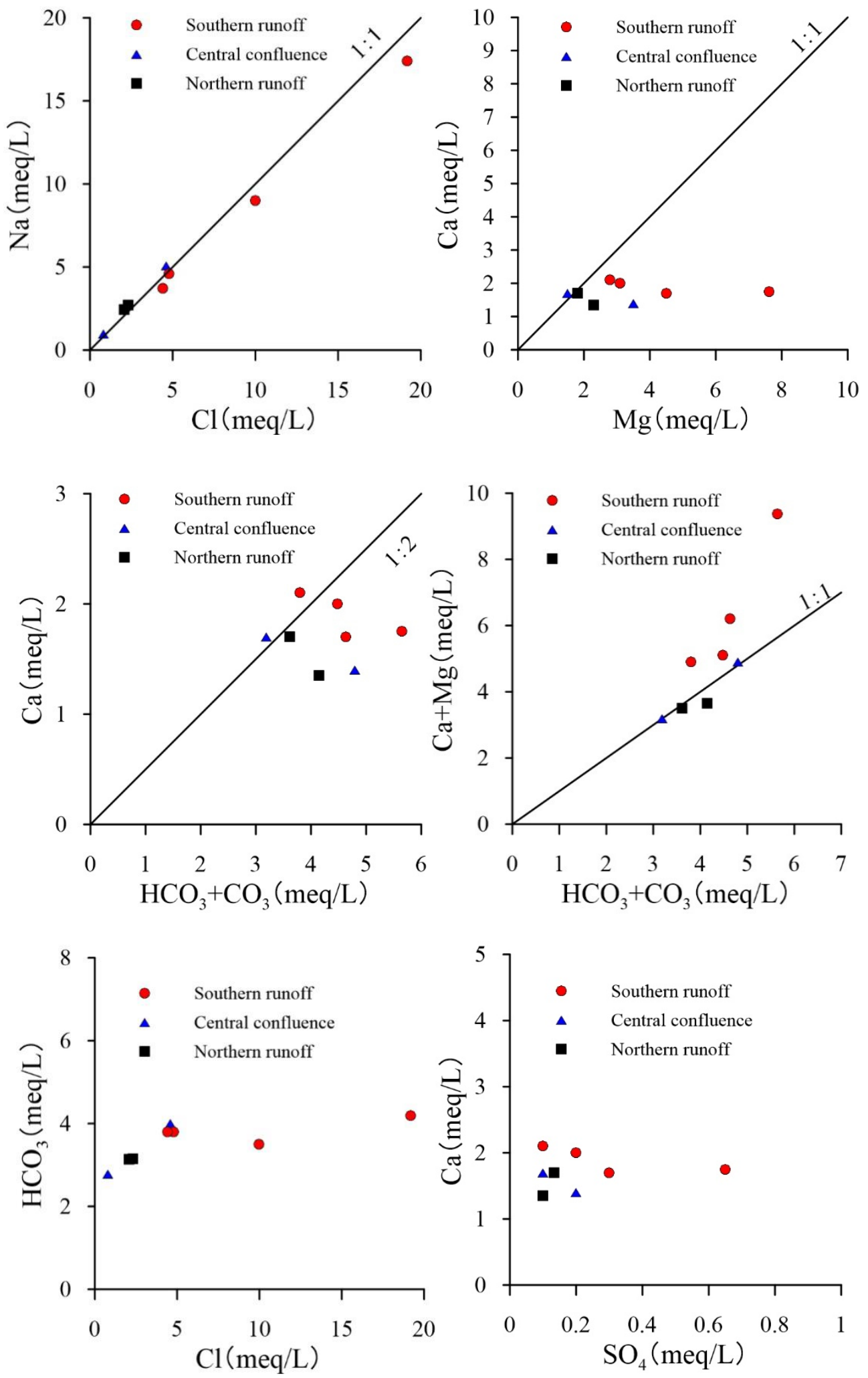

Figure 14. Bivariate diagrams of ionic concentrations in lake water.

\subsection{1. $\mathrm{Na} / \mathrm{Cl}$}

The $\mathrm{Na} / \mathrm{Cl}$ ratio is a measure of the extent of salt leaching and accumulation, which is used to measure the degree of $\mathrm{Na}$ enrichment in groundwater. The groundwater $\mathrm{Na} / \mathrm{Cl}$ ratio in both the southern and northern runoff areas is close to 1 , where halite dissolution mainly occurs. The $\mathrm{Na} / \mathrm{Cl}$ 
ratios in the central area are between 1.47 and 1.75. A comparison of the northern and southern regions shows that $\mathrm{Na}^{+}$concentrations may be affected by the alternate adsorption of the cations. Moreover, the $\mathrm{Na} / \mathrm{Cl}$ ratio in the lake water is almost close to 1 , suggesting that only halite dissolution occurs.

\subsection{2. $(\mathrm{Ca}+\mathrm{Mg}) / \mathrm{HCO}_{3}$}

The $(\mathrm{Ca}+\mathrm{Mg}) / \mathrm{HCO}_{3}{ }^{-}$ratio is an indicator of whether hydrochemical processes other than carbonate dissolution occur in groundwater. The $(\mathrm{Ca}+\mathrm{Mg}) / \mathrm{HCO}_{3}{ }^{-}$ratios in $\mathrm{ZK03}$ and $\mathrm{ZK} 07$ are much greater than 1 , indicating that both carbonate dissolution and the inverse reaction of alternate adsorption of cations occur. The $(\mathrm{Ca}+\mathrm{Mg}) / \mathrm{HCO}_{3}{ }^{-}$ratio at ZK09 is slightly greater than 1 . Further, the $\mathrm{SO}_{4}{ }^{2-}$ concentration is high, which is because of the dissolution of gypsum and carbonate. Except for ZK03, $\mathrm{ZK} 07$, and $\mathrm{ZK} 09$, the $(\mathrm{Ca}+\mathrm{Mg}) / \mathrm{HCO}_{3}{ }^{-}$ratios are close to 1 , indicating that carbonate dissolution mainly occurs there. Carbonate dissolution mainly occurred in the areas where water samples of L01, L03, L05, L06, L07, and L08 were collected. Carbonate dissolution in the L02 and L04 water samples also resulted in the reverse reaction of the alternate adsorption of the cations. The $(\mathrm{Ca}+\mathrm{Mg}) / \mathrm{HCO}_{3}{ }^{-}$ results and soluble $\mathrm{SiO}_{2}$ concentrations in the whole study area show that silicate dissolution occurs in the groundwater.

\subsection{3. $\mathrm{Ca} / \mathrm{Mg}$ and $\mathrm{Ca} / \mathrm{HCO}_{3}$}

The concentration of $\mathrm{Mg}^{2+}$ is higher than that of $\mathrm{Ca}^{2+}$ at $Z K 09$, suggesting that dolomite and gypsum are the main dissolved minerals. The Ca/Mg ratios for ZK05, ZK06, ZK08, and ZK10 are close to 1 , while the $\mathrm{Ca} / \mathrm{HCO}_{3}{ }^{-}$ratios re close to 0.5 , suggesting that the ratios are only affected by dolomite dissolution in these areas. The $\mathrm{Ca} / \mathrm{Mg}$ ratios of ZK01, ZK04, and ZK11 are 1.94, 1.38, and 1.93, respectively, and the $\mathrm{Ca} / \mathrm{HCO}_{3}$ ratios are $0.60,0.78$, and 0.44 , respectively, which confirms that dolomite and calcite dissolution occurred in these areas.

The $\mathrm{Ca} / \mathrm{Mg}$ ratios for $\mathrm{L} 06$ and $\mathrm{L} 07$ are about 1 , while the ratios for other lake water samples are less than 1. Furthermore, the $\mathrm{Ca} /\left(\mathrm{HCO}_{3}{ }^{-}+\mathrm{CO}_{3}{ }^{2-}\right)$ ratios of $\mathrm{L} 06$ and $\mathrm{L} 07$ are close to 0.5 , whereas those of other lakes are less than 0.5 . These results show that dolomite dissolution is the main process in all of the lakes in the study region.

\subsection{4. $\mathrm{HCO}_{3} / \mathrm{Cl}$}

In the southern region, with the decrease in TDS, the $\mathrm{HCO}_{3} / \mathrm{Cl}$ ratio increases, while the ratios for the lake water samples are in the range of 0.28-2.04. Furthermore, for L05, L07, and L08, the ratios are less than 1, indicating that the main anion in the groundwater and lake water in these areas is $\mathrm{Cl}^{-}$. The $\mathrm{HCO}_{3} / \mathrm{Cl}$ ratios in the central region and the northern region are greater than 1 ; in L01, L02, L03, $\mathrm{L} 04$, and $\mathrm{L} 06$, the ratios are greater than 1 , indicating that $\mathrm{HCO}_{3}{ }^{-}$is the main anion.

\subsection{5. $\mathrm{Ca} / \mathrm{SO}_{4}$}

The $\mathrm{Ca} / \mathrm{SO}_{4}$ ratio at $\mathrm{ZK} 09$ alone is less than $1 / 3$, while the ratio in other areas is greater than or equal to $1 / 3$. Thus, there is a small amount of gypsum dissolution in only some regions of the study area. From the Piper diagram (Figure 7), it can be seen that the Mg equivalent percentage of $\mathrm{SO}_{4}{ }^{2-}$ in the lake water is almost 0 , which suggests that almost no gypsum dissolution occurs in the lakes.

According to the analysis of the ion proportion coefficient mentioned above, the main hydrochemistry in the study area involves weathering, dissolution, precipitation, cationic alternating adsorption, and evaporation. To further understand the thermodynamic process in water, saturation index (SI) is used frequently due to its convenience for mineral equilibrium calculations. The SI values for each mineral are listed in Tables 2 and 3. 
Table 2. Saturation index values of minerals in groundwater.

\begin{tabular}{ccccccc}
\hline Groundwater & Anhydrite & Aragonite & Calcite & Dolomite & Gypsum & Halite \\
\hline ZK01 & -0.14 & 2.94 & 3.1 & 5.52 & 0.11 & -3.73 \\
ZK02 & 0.3 & 2.7 & 2.86 & 5.13 & 0.54 & -3.3 \\
ZK03 & 0.37 & 2.82 & 2.98 & 5.61 & 0.6 & -2.4 \\
ZK04 & 0.04 & 2.79 & 2.95 & 5.36 & 0.29 & -3.19 \\
ZK05 & 0.21 & 2.94 & 3.1 & 5.65 & 0.45 & -3.51 \\
ZK06 & 0.15 & 2.87 & 3.02 & 5.48 & 0.39 & -3.51 \\
ZK07 & 0.58 & 2.75 & 2.91 & 5.41 & 0.82 & -2.84 \\
ZK08 & 0.29 & 2.68 & 2.84 & 5.08 & 0.54 & -3.57 \\
ZK09 & 0.51 & 2.6 & 2.75 & 5.34 & 0.75 & -3.28 \\
ZK10 & 0.09 & 2.97 & 3.12 & 5.81 & 0.33 & -3.59 \\
ZK11 & -0.39 & 2.64 & 2.8 & 4.89 & -0.15 & -3.47 \\
\hline
\end{tabular}

Table 3. Saturation index values of minerals in lake water.

\begin{tabular}{ccccccc}
\hline Lake & Anhydrite & Aragonite & Calcite & Dolomite & Gypsum & Halite \\
\hline L01 & -0.79 & 3.16 & 3.31 & 5.97 & -0.55 & -3.65 \\
L02 & -0.78 & 3.26 & 3.40 & 6.56 & -0.54 & -3.06 \\
L03 & -0.97 & 2.88 & 3.03 & 6.00 & -0.73 & -3.76 \\
L04 & -0.58 & 3.26 & 3.41 & 6.85 & -0.35 & -2.51 \\
L05 & -0.99 & 3.11 & 3.26 & 6.10 & -0.75 & -3.63 \\
L06 & -0.96 & 3.01 & 3.16 & 5.40 & -0.71 & -5.04 \\
L07 & -0.93 & 2.97 & 3.14 & 5.41 & -0.69 & -4.46 \\
L08 & -1.23 & 3.245 & 3.395 & 6.33 & -0.99 & -4.18 \\
\hline
\end{tabular}

There is no significant difference in the dissolution degrees of the groundwater minerals, except gypsum and anhydrite. Anhydrite and gypsum are basically in equilibrium in the groundwater in the study area. Aragonite, calcite, and dolomite all reach saturation, while halite does not. These results, along with the ion ratio analysis results, indicate that the dolomite dissolution is the main groundwater process in the area. The main dissolved minerals in lake water are halite and dolomite, with a small amount of gypsum and anhydrite dissolution evident in some areas.

\subsection{Stable Isotope Characteristics}

Stable isotopes have been widely used to explore the sources of various water bodies and to study the quantitative relationship between groundwater and surface water $[7,34,35]$. The statistical analysis results for isotopic content detection are shown in Table 4.

Table 4. Statistical analysis results for $\delta \mathrm{D}$ and $\delta^{18} \mathrm{O}$ contents in lakes and groundwater.

\begin{tabular}{lcccc}
\hline & Groundwater & \multicolumn{2}{c}{ Lake Water } \\
\hline Index & $\delta^{18} \mathrm{O}$ & $\delta \mathrm{D}$ & $\delta^{18} \mathrm{O}$ & $\delta \mathrm{D}$ \\
\hline Minimum & -9.79 & -70.563 & -9.26 & -64.114 \\
Maximum & -4.574 & -43.951 & -4.218 & -36.372 \\
Mean & -8.453 & -60.644 & -6.01 & -45.718 \\
\hline
\end{tabular}

According to the global precipitation data in 1961, Craig proposed that there is a certain linear relationship between the contents of $\delta \mathrm{D}$ and $\delta^{18} \mathrm{O}$ in the precipitation, as follows [36]:

$$
\delta \mathrm{D}=8 \delta^{18} \mathrm{O}+10
$$

Obviously, the variations of $\delta \mathrm{D}$ and $\delta^{18} \mathrm{O}$ contents are almost synchronous during the formation of atmospheric precipitation. The $\delta \mathrm{D}$ value is about 8 times higher than that of $\delta^{18} \mathrm{O}$, which is mainly 
caused by the dynamic fractionation during evaporation. The contents of $\delta \mathrm{D}$ and $\delta^{18} \mathrm{O}$ for precipitation in different regions are affected by many factors, such as temperature, continental changes, rainfall, dimensions, and mountain shielding, suggesting that there are different linear relationships between $\delta \mathrm{D}$ and $\delta^{18} \mathrm{O}$ contents $[6,16,31,36,37]$.

Precipitation in the study region will be fractionated to different degrees during the formation process due to the special geographical location and topography characteristics, resulting in the local meteoric water line (LMWL) here being significantly different from the global meteoric water line (GMWL) (Figure 15) [21,32]. Based on the precipitation isotopic data for the BLB collected from Wudaoliang and Tuotuohe meteorological stations, the equation for the summer atmospheric waterline in Beiluhe is obtained as follows [36]:

$$
\delta \mathrm{D}=7.82 \delta^{18} \mathrm{O}+15.52
$$

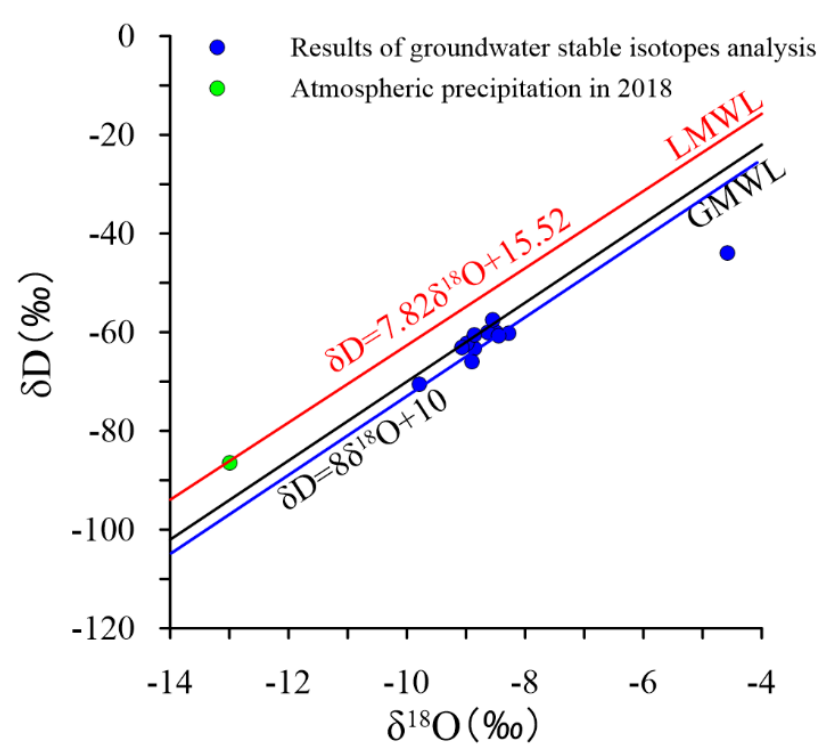

Figure 15. Diagram of the global meteoric water line (GMWL) and local meteoric water line.

The atmospheric precipitation $\delta^{18} \mathrm{O}$ is $-12.998 \%$ ond $\delta \mathrm{D}$ is $-86.466 \%$, which fit well with the above precipitation equation. The LMWL of the BLB is higher than the GMWL, with an intercept of about $8 \%$, indicating that the deviation degree of $\delta \mathrm{D}$ in the secondary equilibrium state of the BLB is quite larger. This suggests that water vapor is affected by multiple evaporation before reaching the surface to form precipitation, which means the $\delta \mathrm{D}$ is continuously enriched and the degree of deviation is increased. However, the slope of the LMWL in the BLB is less than that of the GMWL. The evaporation is $3-4$ times higher than the precipitation. This elucidates that the precipitation water vapor mass has a mixed isotope effect with the water vapor mass formed by evaporation of surface water or ecological water bodies, making the slope of the LMWL smaller. Therefore, atmospheric precipitation is an important source of lake supply and isotope enrichment.

The difference between $\delta \mathrm{D}$ and $\delta^{18} \mathrm{O}$ is quite small and is different from other regions because of the sampling point, which is located in the lower part of the LMWL, as well as the high humidity during sampling period $[6,11]$. The results shown in Table 4 indicate that lakes are more likely to be enriched with heavy isotopes than the groundwater under the same climatic conditions.

The analysis of the hydrochemistry of lakes and groundwater suggests that evaporation has a significant influence on the hydrochemical components. Therefore, the evaporation intensity is verified and analyzed by calculating the E/I of lakes by using the formula proposed by Horita et al., Gonfiantini et al., Edwards et al., and Birks et al. [36-39].

According to the real-time temperature and relative humidity data provided by Wudaoliang and Tuotuohe meteorological stations, the average relative humidity and temperature of the study area 
were $60.032 \%$ and $278.51 \mathrm{~K}$, respectively. Furthermore, the $\delta^{18}{ }_{1} \mathrm{O}$ and $\delta_{1} \mathrm{D}$ values were -12.55 and -82.621 , respectively. The E/I calculation results are shown in Table 5.

Table 5. E/I calculation results.

\begin{tabular}{ccc}
\hline Lake & Calculated with ${ }^{\mathbf{1 8}} \mathbf{O}$ & Calculated with D \\
\hline L01 & 0.52 & 1.09 \\
L02 & 0.56 & 1.11 \\
L03 & 0.58 & 1.24 \\
L04 & 0.68 & 1.35 \\
L05 & 0.29 & 0.47 \\
L06 & 0.17 & 0.27 \\
L07 & 0.24 & 0.28 \\
\hline
\end{tabular}

A comparison of the two sets of calculation results shows that ${ }^{18} \mathrm{O}$ is more stable than $\mathrm{D}$, which confirms that the calculation results for $\delta^{18} \mathrm{O}$ are reasonable. The lake $\mathrm{E} / \mathrm{I}$ calculated with $\delta^{18} \mathrm{O}$ varies in the range of $0.17-0.68$, and the highest value (0.68) of LO4 confirms the validity of the above hydrochemical analysis results. When $\mathrm{E} / \mathrm{I}$ is less than 1, evaporation from the lake is less significant than recharge, so the lake area will gradually increase. It can be inferred that a thermokarst lake will gradually drain until it disappears after a long-term change. At that time, the isotopic content percentage in the lake reaches the maximum; that is, $\delta^{*}$. According to field survey data, the ultimate limit values of $\delta^{*} \mathrm{D}$ and $\delta^{* 18} \mathrm{O}$ of the lake in the study area are -9.318 and $4.099 \%$, respectively.

\section{Conclusions}

In this study, hydrochemical characteristics and water isotope compositions $\left(\delta^{18} \mathrm{O}\right.$ and $\left.\delta \mathrm{D}\right)$ of thermokarst lake water and groundwater were studied systematically during the melting of the permafrost in the QTP.

The major mechanisms that control the chemical composition of the lakes and groundwater are the same and contain the evaporation-fractional crystallization process and rock weathering. There are three main hydrogeochemical processes that occur in the formation of lakes and groundwater hydrochemistry: dissolution-precipitation, cation exchange, and evaporation-fractional crystallization. The directions of cation exchange between lakes and groundwater are basically the same, but the exchange amount for lakes is less than that of groundwater. The main dissolved minerals in lakes and groundwater are halite and carbonate, while a small amount of silicate is dissolved. The mainly carbonate is dolomite, while a small amount of calcification is dissolved in some areas. The difference between lakes and groundwater is that the solubility of sulphate in groundwater is slightly higher than that of lakes.

According to the study of the isotope relationship map, it can be determined that the sources of recharge of thermokarst lakes include atmospheric precipitation, groundwater, and permafrost meltwater. The E/I ratios were $<1$ for all thermokarst lakes, suggesting that all of the lakes are in a continuous expansion stage. This is directly proved by isotope endmember analysis, showing that the characteristics of the water's chemical composition are not only affected by the chemical characteristics of recharge source water, but also by evaporation. Towards a comprehensive understanding of the hydrochemical processes in thermokarst lakes, our work encourages further research on protecting the ecology and environment of the QTP.

Author Contributions: Conceptualization, W.W., J.L. (Jinlong Li), and J.D.; methodology, W.W., D.W., and J.D.; writing —original draft preparation, J.L. (Jinlong Li) and J.L. (Jiaqi Li); writing-review and editing, J.L. (Jinlong Li) and D.W. All authors have read and agreed to the published version of the manuscript.

Funding: This research was funded by National Science Foundation of China, Grant No. 41730640_Environmental and Hydrological Effects of the Thermokarst Lakes in the Permafrost Region of the QTP; and the Fundamental Research Funds for the Central Universities, CHD, Grant No. 300102290401. 
Acknowledgments: This research was mainly supported by Cold and Arid Regions Environmental and Engineering Research Institute, Chinese Academy of Sciences. All authors sincerely thank the researchers and staff members for their help and thanks in-house editors and reviewers for reviewing the manuscript. Additionally, sincerely thanks Selva Zhu for her support on language.

Conflicts of Interest: The authors declare no conflict of interest.

\section{References}

1. Ran, Y.; Li, X.; Cheng, G.-D. Climate warming over the past half century has led to thermal degradation of permafrost on the Qinghai-Tibet Plateau. Cryosphere 2018, 12, 595-608. [CrossRef]

2. Qin, Y.; Lei, H.; Yang, D.; Gao, B.; Wang, Y.; Cong, Z.; Fan, W. Long-term change in the depth of seasonally frozen ground and its ecohydrological impacts in the Qilian Mountains, northeastern Tibetan Plateau. J. Hydrol. 2016, 542, 204-221. [CrossRef]

3. Throckmorton, H.; Newman, B.D.; Heikoop, J.M.; Perkins, G.; Feng, X.; Graham, D.E.; O’Malley, D.; Vesselinov, V.V.; Young, J.; Wullschleger, S.D.; et al. Active layer hydrology in an arctic tundra ecosystem: Quantifying water sources and cycling using water stable isotopes. Hydrol. Process. 2016, 30, 4972-4986. [CrossRef]

4. Niu, F.; Lin, Z.; Liu, H.; Lu, J. Characteristics of thermokarst lakes and their influence on permafrost in Qinghai-Tibet Plateau. Geomorphology 2011, 132, 222-233. [CrossRef]

5. Polishchuk, Y.M.; Bogdanov, A.N.; Polishchuk, V.Y.; Manasypov, R.; Shirokova, L.S.; Kirpotin, S.N.; Pokrovsky, O. Size Distribution, Surface Coverage, Water, Carbon, and Metal Storage of Thermokarst Lakes in the Permafrost Zone of the Western Siberia Lowland. Water 2017, 9, 228. [CrossRef]

6. Gao, Z.; Niu, F.; Lin, Z.; Luo, J.; Yin, G.; Wang, Y. Evaluation of thermokarst lake water balance in the Qinghai-Tibet Plateau via isotope tracers. Sci. Total Environ. 2018, 636, 1-11. [CrossRef] [PubMed]

7. Lin, Z.; Luo, J.; Niu, F. Development of a thermokarst lake and its effects on permafrost over nearly $10 \mathrm{yr}$ in the Beiluhe Basin, Qinghai-Tibet Plateau. Geosphere 2016, 12, 632-643. [CrossRef]

8. Fang, J.; Xu, A.; Yang, Y.; Zhang, Z. Hydrological changes and engineering implications of thermokarst lakes, Qinghai-Tibet Plateau. J. Cap. Norm. Univ. 2019, 40, 54-60.

9. Painter, S.L.; Moulton, J.D.; Wilson, C.J. Modeling challenges for predicting hydrologic response to degrading permafrost. Hydrogeol. J. 2013, 21, 221-224. [CrossRef]

10. Sefie, A.; Aris, A.Z.; Ramli, M.F.; Narany, T.S.; Shamsuddin, M.K.N.; Saadudin, S.B.; Zali, M.A. Hydrogeochemistry and groundwater quality assessment of the multilayered aquifer in Lower Kelantan Basin, Kelantan, Malaysia. Environ. Earth Sci. 2018, 77, 397. [CrossRef]

11. Wang, L.; Dong, Y.; Xu, Z.; Qiao, X. Hydrochemical and isotopic characteristics of groundwater in the northeastern Tennger Desert, northern China. Hydrogeol. J. 2017, 25, 2363-2375. [CrossRef]

12. Piper, A.M. A graphical procedure in the geochemical interpretation of water analysis. Eos Trans. Am. Geophys. Union 1944, 25, 914-928. [CrossRef]

13. Gibbs, R.J. Mechanisms Controlling World Water Chemistry. Science 1970, 170, 1088-1090. [CrossRef] [PubMed]

14. Liu, J.; Jin, D.; Wang, T.; Gao, M.; Yang, J.; Wang, Q. Hydrogeochemical processes and quality assessment of shallow groundwater in Chenqi coalfield, Inner Mongolia, China. Environ. Earth Sci. 2019, 78, 347. [CrossRef]

15. Singh, A.K.; Mahato, M.K.; Neogi, B.; Singh, K.K.; Mahato, M.K. Quality Assessment of Mine Water in the Raniganj Coalfield Area, India. Mine Water Environ. 2010, 29, 248-262. [CrossRef]

16. Huang, X.; Wang, G.; Liang, X.; Cui, L.; Ma, L.; Xu, Q. Hydrochemical and Stable Isotope $\left(\delta \mathrm{D}\right.$ and $\left.\delta^{18} \mathrm{O}\right)$ Characteristics of Groundwater and Hydrogeochemical Processes in the Ningtiaota Coalfield, Northwest China. Mine Water Environ. 2017, 37, 119-136. [CrossRef]

17. Li, P.; Qian, H.; Wu, J.; Zhang, Y.; Zhang, H. Major ion chemistryof shallow groundwater in the Dongsheng Coalfield, OrdosBasin China. Mine Water Environ. 2013, 32, 195-206. [CrossRef]

18. Li, P.; Wu, J.; Qian, H. Assessment of groundwater quality for irrigation purposes and identification of hydrogeochemical evolution mechanisms in Pengyang County, China. Environ. Earth Sci. 2012, 69, 2211-2225. [CrossRef] 
19. Cloutier, V.; Lefebvre, R.; Therrien, R.; Savard, M.M. Multivariate statistical analysis of geochemical data as indicative of the hydrogeochemical evolution of groundwater in a sedimentary rock aquifer system. J. Hydrol. 2008, 353, 294-313. [CrossRef]

20. Wang, X.; Li, S.; Liu, C.; Mostofa, K.M.G.; Zhao, Z.; Luo, R. Hydrogeochemistry and ${ }^{13} \mathrm{C}_{\text {DIC }}$ and ${ }^{18} \mathrm{O}$ composition of three Chinese Tibetan Plateau lakes. Isot. Environ. Health Stud. 2017, 54, 89-105. [CrossRef]

21. Gao, Z.; Lin, Z.; Niu, F.; Luo, J.; Liu, M.; Yin, G. Hydrochemistryand controllingmechanism of lakes in permafrost regions along the Qinghai-Tibet Engineering Corridor, China. Geomorphology 2017, 297, 159-169. [CrossRef]

22. Yang, Y.; Wu, Q.; Yun, H.; Jin, H.; Zhang, Z. Evaluation of the hydrological contributions of permafrost to the thermokarst lakes on the Qinghai-Tibet Plateau using stable isotopes. Glob. Planet. Chang. 2016, 140, 1-8. [CrossRef]

23. Li, X.-Y.; Ma, Y.-J.; Huang, Y.-M.; Hu, X.; Wu, X.; Wang, P.; Li, G.-Y.; Zhang, S.-Y.; Wu, H.-W.; Jiang, Z.-Y.; et al. Evaporation and surface energy budget over the largest high-altitude saline lake on the Qinghai-Tibet Plateau. J. Geophys. Res. Atmos. 2016, 121, 10470-10485. [CrossRef]

24. Cheng, G.; Jin, H. Permafrost and groundwater on the Qinghai-Tibet Plateau and in northeast China. Hydrogeol. J. 2013, 21, 5-23. [CrossRef]

25. Guo, L.; Yu, Q.; You, Y.; Wang, X.; Yuan, C.; Li, X. Evaluation on the influences of lakes on the thermal regimes of nearby tower foundations along the Qinghai-Tibet Power Transmission Line. Appl. Therm. Eng. 2016, 102, 829-840. [CrossRef]

26. Zhou, Y.; Guo, D.; Qiu, G.; Cheng, G.; Li, S. Geocryology in China; Science Press: Beijing, China, 2000; pp. 1-34. (In Chinese)

27. Cheng, G.; Wu, I. Response of permafrost to climate change and their environmental significance, Qinghai-Tibet Plateau. J. Geophys. Res. 2007, 112, F02S03. [CrossRef]

28. Ge, S.; McKenzie, J.; Voss, C.; Wu, Q. Exchange of groundwater and surface-water mediated by permafrost response to seasonal and long term air temperature variation. Geophys. Res. Lett. 2011, 38, L14402. [CrossRef]

29. Zhou, P.; Wang, Z.; Zhang, J.; Yang, Z.; Li, X. Study on the hydrochemical characteristics of groundwater along the Taklimakan Desert Highway. Environ. Earth Sci. 2016, 75, 1378. [CrossRef]

30. Wu, C.; Wu, X.; Qian, C.; Zhu, G. Hydrogeochemistry and groundwater quality assessment of high fluoride levels in the Yanchi endorheic region, northwest China. Appl. Geochem. 2018, 98, 404-417. [CrossRef]

31. Li, P.; Zhang, Y.; Yang, N.; Jing, L.; Yu, P. Major Ion Chemistry and Quality Assessment of Groundwater in and Around a Mountainous Tourist Town of China. Expo. Health 2016, 8, 239-252. [CrossRef]

32. Gao, Z.; Liu, J.; Feng, J.; Wang, M.; Wu, G. Hydrogeochemical Characteristics and the Suitability of Groundwater in the Alluvial-Diluvial Plain of Southwest Shandong Province, China. Water 2019, 11, 1577. [CrossRef]

33. Schoeller, H. Qualitative evaluation of groundwater resources. In Methods and Techniques of Groundwater Investigation and Development, Water Resource Series No. 33; UNESCO: Paris, France, 1967; pp. 44-52.

34. Horita, J.; Wesolowski, D.J. Liquid-vapor fractionation of oxygen and hydrogen isotopes of water from the freezing to the critical temperature. Geochim. Cosmochim. Acta 1994, 58, 3425-3437. [CrossRef]

35. Qian, H.; Dou, Y.; Li, X. The variation of stable isotopes of hydrogen and oxygen along the flow and its indication for river evaporation in dousitu river. Hydrogeol. Eng. Geol. 2007, 28, 107-112.

36. Yang, Y.; Wu, Q.; Yun, H. Analysis of Stable isotope of precipitation and river water in permafrost area, Qinghai-Tibet Plateau, beiluhe basin. Adv. Water Sci. 2013, 24, 778-785.

37. Gonfiantini, R. Environmental isotopes in lake studies. In Handbook of Environmental Isotope Geochemistry; Elsevier: Amsterdam, The Netherlands, 1986; pp. 113-168.

38. Gibson, J.; Edwards, T.W.D. Regional water balance trends and evaporation-transpiration partitioning from a stable isotope survey of lakes in northern Canada. Glob. Biogeochem. Cycles 2002, 16, 10-1-10-14. [CrossRef]

39. Gibson, J.; Birks, S.; Yi, Y. Stable isotope mass balance of lakes: A contemporary perspective. Quat. Sci. Rev. 2016, 131, 316-328. [CrossRef]

(C) 2020 by the authors. Licensee MDPI, Basel, Switzerland. This article is an open access article distributed under the terms and conditions of the Creative Commons Attribution (CC BY) license (http://creativecommons.org/licenses/by/4.0/). 